Meta

Journal des traducteurs

Translators' Journal

\title{
Two Different Translations of Tennyson's The Idylls of the King into Spanish: The Road From a Text-Oriented Model to a Functional Model of Translation
}

\section{Juan Miguel Zarandona}

Volume 53, numéro 3, septembre 2008

URI : https://id.erudit.org/iderudit/019236ar

DOI : https://doi.org/10.7202/019236ar

Aller au sommaire du numéro

Éditeur(s)

Les Presses de l'Université de Montréal

ISSN

0026-0452 (imprimé)

1492-1421 (numérique)

Découvrir la revue

Citer cet article

Zarandona, J. M. (2008). Two Different Translations of Tennyson's The Idylls of the King into Spanish: The Road From a Text-Oriented Model to a Functional Model of Translation. Meta, 53(3), 490-506. https://doi.org/10.7202/019236ar
Résumé de l'article

Cet article présente une étude détaillée de deux traductions espagnoles, très différentes entre elles, de certains idylles de Tennyson, qui se trouvent dans son principal ouvrage arthurique, The Idylls of the King ( $\mathrm{XIX}^{\mathrm{e}}$ siècle). Ce travail s'appuie sur deux modèles d'analyse différents : l'analyse textuelle de Juliane House et l'analyse fonctionnelle de Christiane Nord. La conclusion veut démontrer que l'évaluation d'une traduction peut changer en fonction des critères utilisés lors du transfert interlinguistique. 


\title{
Two Different Translations of Tennyson's The Idylls of the King into Spanish: The Road From a Text-Oriented Model to a Functional Model of Translation
}

\author{
JUAN MIGUEL ZARANDONA \\ Universidad de Valladolid, Valladolid, Spain \\ zarandon@lia.uva.es
}

\begin{abstract}
RÉSUMÉ
Cet article présente une étude détaillée de deux traductions espagnoles, très différentes entre elles, de certains idylles de Tennyson, qui se trouvent dans son principal ouvrage arthurique, The Idylls of the King ( $\mathrm{x} \mathrm{x}^{\mathrm{e}}$ siècle). Ce travail s'appuie sur deux modèles d'analyse différents: l'analyse textuelle de Juliane House et l'analyse fonctionnelle de Christiane Nord. La conclusion veut démontrer que l'évaluation d'une traduction peut changer en fonction des critères utilisés lors du transfert interlinguistique.
\end{abstract}

\begin{abstract}
This article studies, in some detail, two very different Spanish translations of some of the idylls of Tennyson included in his greatest Arthurian work: The Idylls of the King (XIXth century). The task is approached by means of two different assessment models, Juliane House's textual one and Christiane Nord's functional one. The final conclusion will lead to the fact that the assessment of a translation may change dramatically depending on the criteria chosen, as it is here clearly the case.
\end{abstract}

\section{MOTS-CLÉS/KEYWORDS}

assessment models, English-Spanish translation, functional, literary translation, Tennyson

\section{Introduction}

The September 15th 2001 issue of The Economist (Books and Arts Section) reviews a new anthology that brings together 29 of Coetzee's book reviews, articles and lectures (Anonymous: 77-78), written over a period of fourteen years. Many of these pieces deal on the art of translation, but, as the reviewer emphasizes, Coetzee refuses to commit himself to a theory of translation, offering instead his elegantly evasive formulation that "translating turns out to be only a more intense and more demanding form of what we do whenever we read" (Anonymous: 77).

The history of translation theory is crowded with supposedly witty, original and successful literary or semi-literary pseudo-formulations of what translation is or the translator does: "les belles infidèles," "traduttore traditore," or what Don Quixote of La Mancha said in Barcelona once:

Pero con todo esto me parece que el traducir de una lengua en otra, como no sea de las reinas de las lenguas griega y latina, es como quien mira los tapices flamencos por el revés, que aunque se ven las figuras, son llenos de hilos que las escurecen, y no se ven 
con la lisura y la tez de la haz; y el traducir de lenguas fáciles, ni arguye ingenio ni elocución, como no le arguye el que traslada ni el que copia un papel de otro papel; y no por esto quiero inferir que no sea loable este ejercicio del traducir, porque en otras cosas peores se podría ocupar el hombre, y que menos provecho le trajesen. (Cervantes 1884: 345$)$

[Though, by the way, sir, I think this kind of version from one language to another, except it be from the noblest of tongues, the Greek and Latin, is like viewing a piece of Flemish tapestry on the wrong side, where though the figures are distinguishable yet there are so many ends and threads that the beauty and exactness of the work is obscured, and not so advantageously discerned as on the right side of the hangings. Neither can this barren employment of translating out of easy languages show either wit or mastery of style, no more than copying a piece of writing by a precedent; though still the business of translating want not its commendations, since men very often may be worse employed]. (Cervantes 1993: 729)

Things are a bit different nowadays. Coetzee does not regard translation from those negative viewpoints any more, but he does not commit with any theory of translation either. He still seems to rely on 'talent,' 'intuition' and 'traditional beautiful approaches to translation' either considered as an art or a very difficult to rationalize experience. I do not necessarily have anything against this surprising standpoint, but the aim of this essay of mine will be of a very different kind.

I will focus on the translation theories of two very prestigious scholars and authorities among professional translators and friends of the study and discussion of the so-called modern translation models: the scientific study of translation, from the most rigorous methodologies and research principles, developed by the new independent discipline named "Translation Studies." In other words, I will contrast text-oriented Juliane House's approach to translation with Christiane Nord's functional one, and exemplify them and their marked differences with the help of some translations of the Arthurian poems by the Victorian poet Alfred Tennyson into Spanish.

\section{House's text-oriented model}

In 1981, the prestigious translation theorist Juliane House made a major contribution to the understanding and evalution of translation by means of her book: A Model for translation quality (25-31, 37-65, 188-211). Since then, her model has always been regarded as one of the leading text-oriented proposals or theoretical models.

Juliane House bases the starting point of her approach on "meaning," as a reality made of three distinguishing domains or aspects: 1) semantic, 2) pragmatic, and 3) textual. In other words, as linguists know well, the denotative relationships of linguistic units or symbols to their references in some possible real or fictional world (1). Then, the connotative correlation between these units and any given communication situation, i.e. the so-called 'illocutionary force' that an utterance is said to have in context, which is extraordinarily meaningful and the key factor in translation according to House. And, finally, the cohesive and coherent interrelation or linkage of all textual elements into the larger unit named, of course, "text" (3).

Consequently, House defines and very emphatically demands translation to be a process involving the replacement of a text in the source language by a semantically 
and pragmatically equivalent text in the target language. Equivalence constitutes the basis of her theoretical contribution to translation study, practice and assessment. The target text must also have a function equivalent to that of the source text.

Because of the overriding higher status given to the source text when translating over the tarter text (domina-ancilla), House emphasizes the analysis of the source texts as the right starting point: the better we know the source text, the better we will be able to produce an equivalent target text or to evaluate an existing translation. As a result, she made use of many previous translatology breakthroughs and devised her own well-known model based on a framework of "situational dimentions," that opens up the linguistic material towards a whole set of extralinguistic or situational constraints. The idea is to get to know any given source text in full detail, what she calls "text or textual profile," and then to make both profiles, the source and the target text ones, equivalent:

A Dimentions of Language User

- Geographical origin

- Social class

- Time

B Dimensions of Language Use

- Medium (simple/complex)

- Participation (simple/complex)

- Social role relationship

- Social attitude

- Province

A few pages later, however, when she offers a typology consisting of two major translation types, House must admit the shortcomings of her model, which she seems not to regard as her own responsibility, but something taken for granted when dealing with the theory and practice of translation. According to House there are two kinds of translation: "overt translation" and "covert translation." She herself points out that the first one leads to important modifications of her model, just explained above, because a direct match of the original, her model's overmastering requirement, is not possible. Overt translation texts are those originating in source texts charged with strong historical or cultural specific features (political speeches, religious sermons, comedy dialogue, etc.). Nobody will regard the product as a second original. Covert translation texts (commercial, scientific, journalistic, tourist information ones), on the other hand, usually enjoy the same status of an original source text in the target culture. The target text is not particularly tied to the source language community and culture, and fulfils equivalent needs of a comparable audience in the target language communities.

In short, for House, although it is always very difficult to achieve, mainly due to interpersonal components, it is only in cases of covert translation that it is in fact possible to achieve or approach her ideal of functional equivalence. Overt translation ones must get satisfied with what is simply called: 'second level function.' Their status as actual translation entities seems clearly diminished under the unequal viewpoint of this translation model.

Juliane House also describes at length a quality assessment method for translated texts, fully coherent with the aforementioned ideas: the source text's textual profile or text function is taken as the norm against which the corresponding target text is 
measured. Matches and mismatches (errors) are carefully scrutinized. But the problem is how to be objective when it is said and seems to be likely that contrastive analyses, even between popular languages such as English and German, are almost non-existent. We must rely on native speaker intuition, corpora of texts, etc., but a subjective and hermeneutic element is always unavoidable. The experience of equivalence is never absolute. There are always degrees of probability. Translation is not a natural science, and that is why its evaluation can never be fully objectified. Both, it seems, must surrender.

\section{Nord's functional model}

In contrast with House's theories, Nord (1991a) (1992: 39-48) (1997: 15-26, 39-103) stresses the intended function of the target translated text, as determined by the initiator of the translation's needs, and not function, content or structure of the source text whatsoever: the criteria in traditional equivalence-based translation theories like House's. In other words, 'translation' is the production of a functional target text maintaining a changing relationship with a given source text which is specified according to the intended or demanded function of the target text, i.e., the translation skopos, the key concept of the so-called Theory of Skopos. Consequently, different translations may preserve different aspects of the original text, and all may be perfectly correct. It depends only on the instructions given. Those instructions or translation needs are the ones to be taken closely into account in order to produce a good translation, and not old-fashioned ideas like those related to faithful (+) / unfaithful (-) 'equivalence' to the source text. A translator may choose or be asked to pay attention to the content only of a source text, or equal attention to content and structure, or to the function or purpose of the target text, which may or may be not different from that of the source text. Consequently, this is the end of the traditional equivalence-based criteria to produce and to assess a specific translation. 'Equivalence' to the source text is not that important any more. A non-equivalent target text, from a semantic, linguistic and/or pragmatic point of view, may be the right or, at least, a better translation than a very equivalent one, if this is what the target text readership wants or needs.

Nord also provides translators with a systematic and most valuable model of translation-text analysis which summarizes all her proposals and by which translation work is led through very clear and safe step-by-step procedures. Basically, the method is as follows:

1) Analyse the translation brief or set of instructions often determined by the initiator of the translation. What is required of the translator?

2) Analyse the source text in terms of the translation brief. Is it possible to fulfil the requirements of the brief?

3) Determine the gist or what the text is about. Is the gist of the material provided by the source text compatible with the requirements stated in the translating instructions?

4) Closer reading or basic text analysis of all aspects of the source text in detail, focusing attention on those elements that according to the translation brief are of particular importance for the production of the target text. These elements are called 'extratextual' and 'intratextual factors' since they relate both to the text itself and to its communicative situation. Nord organizes them in a double set or checklist of 
questions. On the one hand, the pragmatic extratextual ones: Who transmits? To whom? What for? By which media? Where? When? Why? With what function? On the other, the semantic and formal ones: On what subject matter? What? What not? In what order? Using which non-verbal elements? In which words? In what kind of sentences? In which tone?

5) Preserve or adapt the source text elements. This starts the actual translation and it is the moment to take into account the intended function of the target text - the ruling one -, i.e., the most important novelty of the model by Nord and her school of translation theory: what source text elements are relevant for the target text, which ones must be adapted or discarded, etc. In other words, here we have the aforementioned end of the old concept of equivalence or the old struggle to achieve some measure of equivalence or similarity between the source and the target texts. The new idea is that the translation can never be exactly the same as the original because of the different cultures at play and because of linguistic differences between languages. So translators must decide what their priorities are in every particular case, depending on what the new translated text is intended for.

6) Do the final structuring of the target text and produce a functional text that fulfils the target text requirements.

7) Go back and find out if the translator has succeeded in producing a functional translation conforming to the initiator's needs, the target text brief and the intended function for the target text, i.e., a circle perfectly rounded.

As the function of both the source and especially the target texts are the key factors for this model, Nord also studies this question in detail and proposes her own translation-oriented model of text functions consisting of four of them: "referential function in translation," "expressive function in translation," "appellative function in translation' and 'phatic function in translation." Many other subfunctions are also included under the labels of these four main ones. A translated text does not need to keep the same function as the source text (equifunctional translation vs heterofunctional translation), but if the purpose of the translaton is to keep the function of the text invariant, function markers must frequently be adapted or changed to target culture standards. If function markers are exactly reproduced, it may induce the target receivers to assign a different function to the target text.

Finally, it must be emphasized that Nord's model is a major contribution but not a total revolution. She makes an effort to get a balance between 'traditional equivalence-based approaches' where the source text is almost everything and 'radical functionalist approaches,' the other extreme position, where the source text is not considered at all. She strives to place her model in a kind of intermediate position, in which the translator has to take account of both the source text and its analysis and the translation skopos. It consists of what it is called the combination of "functionality + loyalty," being this second element a kind of responsibility or respect towards the author and the source text in order to make compatible what can be made compatible (Nord 1991b: 91-109).

\section{Both models compared}

If it is not clear yet that I seem to prefer Nord's model rather than House's one, the following table will more clearly establish my temporary opinion about this question. 


\begin{tabular}{|c|c|}
\hline H O U S E & N O R D \\
\hline $\begin{array}{l}\text { 1. A solid linguistic background. A most } \\
\text { pure linguistic approach to translation. } \\
\text { The pragmatics paradigm is the key } \\
\text { basis or model framework. }\end{array}$ & $\begin{array}{l}\text { 1. Linguistic knowledge is presupposed. Next to } \\
\text { pragmatics insights (extratextual factors), it shows } \\
\text { a deep interest in other things. A more indepen- } \\
\text { dent, from the realm of linguistics, approach to } \\
\text { translation. }\end{array}$ \\
\hline $\begin{array}{l}\text { 2. Very theoretical. Full of high } \\
\text { thinking and abstract ideas. } \\
\text { Intelligent and profound. }\end{array}$ & $\begin{array}{l}\text { 2. More practical. Also applied or oriented to } \\
\text { students of translation and professional transla- } \\
\text { tors. } \\
\text { Witty and brilliant. }\end{array}$ \\
\hline $\begin{array}{l}\text { 3. More traditional: text oriented. } \\
\text { Although a very sophisticated reformu- } \\
\text { lation of it, she believes in equivalence. }\end{array}$ & $\begin{array}{l}\text { 3. One step further. Vivid profanation of a well } \\
\text { established tradition. } \\
\text { Making the way to an almost revolutionary } \\
\text { approach. }\end{array}$ \\
\hline $\begin{array}{l}\text { 4. Seeks an impossible ideal: equivalence } \\
\text { beyond languages and cultures. This } \\
\text { fact is clearly admitted. } \\
\text { A feeling of surrender. }\end{array}$ & $\begin{array}{l}\text { 4. Not impossible goals. More sensible and } \\
\text { realistic. Full of common sense. } \\
\text { A feeling of never giving up. }\end{array}$ \\
\hline $\begin{array}{l}\text { 5. The source text rules. } \\
\text { Both source text and target text must } \\
\text { display the same function or text profile. } \\
\text { Main quality assessment guideline. }\end{array}$ & $\begin{array}{l}\text { 5. The target text, the new creation, the real aim of } \\
\text { the whole process, rules. Dethronement of the } \\
\text { source text. There is no obligation or need to keep } \\
\text { the same function. Not a quality guideline at all. }\end{array}$ \\
\hline $\begin{array}{l}\text { 6. First, equivalence to the source text, } \\
\text { which also includes the same text } \\
\text { function (secondary concept). }\end{array}$ & $\begin{array}{l}\text { 6. The function of the source text is what really } \\
\text { matters. This is the leading idea. Equivalence is } \\
\text { very secondary. } \\
\text { Translation is possible. Equivalence is impossible. }\end{array}$ \\
\hline $\begin{array}{l}\text { 7. Presciptive. Translation must be this } \\
\text { and that, no matter how difficult or } \\
\text { impossible it is. }\end{array}$ & $\begin{array}{l}\text { 7. Descriptive of the reality. It is a fact that } \\
\text { functional translations are produced non-stop } \\
\text { everyday. }\end{array}$ \\
\hline $\begin{array}{l}\text { 8. Very rigid but it admits many } \\
\text { shortcomings and impossibilities. } \\
\text { Contradictory. }\end{array}$ & $\begin{array}{l}\text { 8. Flexible. More balanced. Relativism. } \\
\text { No shortcomings, gaps, impossibilities or } \\
\text { exceptions admitted. }\end{array}$ \\
\hline $\begin{array}{l}\text { 9. Nearer to commonplace ideas about } \\
\text { how poor translation can be and can } \\
\text { dream of being. Closer to more gener- } \\
\text { ally accepted and well known old } \\
\text { clichés. }\end{array}$ & $\begin{array}{l}\text { 9. Vivid profanation. Novelty. Much in need of } \\
\text { spreading the news. } \\
\text { Lots of misunderstanding. }\end{array}$ \\
\hline $\begin{array}{l}\text { 10. Translation is a difficult problem } \\
\text { (semantic, pragmatic, textual equiva- } \\
\text { lence), same function, impossible aims, } \\
\text { etc. Pessimistic viewpoint. }\end{array}$ & $\begin{array}{l}\text { 10. Translation is a set of choices, a decision- } \\
\text { making progress (it depends), a rewarding } \\
\text { challenge. Optimistic viewpoint. }\end{array}$ \\
\hline
\end{tabular}

\section{The models and the practising translator}

This point will focus on two very different practising Spanish translators of Tennyson and his Arthurian Idylls: a late nineteenth-century man of letters, Lope Gisbert, and a late twentieth-century scholar, Ramón Sainero. 


\subsection{Tennyson and The Idylls of the King}

The translation of the outstanding excellence of the poetry of Alfred Tennyson, to any existing language, has always been regarded as a semi-impossible equivalence challenge, and it is not very difficult to understand why.

Amongst the endless bibliography, captivated and revealing statements of his poetical talents like the following abound:

- Walter Irving, his contemporary wrote that: "And yet Mr Tennyson is a great poet; he is the prince of dactylists; he is vigorous and archaic; his similes are beautiful; he is profound; few can fathon him; fewer understand him" (1873: 25), something that is not likely to encourage precisely any translator to translate Tennyson.

- Willis Boughton, for example, equally emphasizes his elevated contents "strong dignity, spiritualized poetry, he is moral, an optimist, he speaks of God, energy nobly controlled" (xvi-xvii), and his unique form: "to adorn his pages with jewels of beauty" (xvii). The poet was also a landmark in the history of British metrics:

Tennyson is the creator of a new blank verse, different both from the Elizabethan and from the Miltonic. He has known how to modulate it to every theme, and to elicit a music appropriate to each; attuning it in turn to a tender and lovely grace, to the severe and ideal majesty of the antique, to meditative thought, to pathetic or tragic tales of contemporary life, or to sustained romantic narration, as in the Idylls. No other English poet has used blank verse with such flexible variety, or drawn from it so large a compass of tones; nor has any maintained it so equally on a high level of excellence. (Boughton: xxi)

- Marjorie Bowden (1930) studies the poor reception of the work of Tennyson in France, and in the Continent in general. She claims that it was due to cultural differences - a too British poet - but, mainly to his peculiar and most difficult literary style, almost impossible to translate.

- In 1936, T.S. Eliot claimed that he was a great poet, for reasons that were perfectly clear (1972: 327). The critic-poet also added that the Victorian poet was a very skilled professional and a master, mainly because of his overwhelming metrical variety (1972: 328).

This is the aforementioned challenge. A challenge rarely faced or issued, but not unknown or non-existing.

\subsection{The Idylls of the King in Spanish}

As mentioned, it is possible to enjoy Tennyson in Spanish verse thanks to the efforts of two very different men, Lope Gisbert and Ramon Sainero, whose only point in common may possibly be their interest in the Victorian.

\subsubsection{Lope Gisbert}

In 1875, when Tennyson was still alive, a Spanish writer and politician, Lope Gisbert, translated into Spanish verse and published in Spain, only two of the Arthurian Idylls by Tennyson: Elaine and Enid: Idilios de Tennyson puestos en verso castellano. Elena, Enid. He kept the name and title of "Enid," but changed slightly the name and title of "Elaine" into "Elena."

Another nineteenth-century Spaniard, Vicente de Arana, devoted admirer of Tennyson, and the most important prose translator of his verse Idylls into Spanish, wrote the following about Lope Gisbert's verse translations a few years later: 
El reputado escritor y hombre público don Lope Gisbert ha hecho un gran servicio á nuestra literatura poniendo en verso castellano el tercero y el quinto de los Idilios del Rey. Es un trabajo admirable por todos conceptos, y esperamos que el señor Gisbert no abandonará la empresa tan gloriosamente empezada, y pondrá también los otros ocho idilios en la hermosa lengua de Castilla. (Arana: XVII)

[The highly reputed writer and politician Mr Lope Gisbert has done a great service to our national literature when rendering the third and the fifth of The Idylls of the King into Castilian verse. His work is admirable from all points of view, and we only hope that Mr Gisbert will not abandon an endeavour so gloriously begun, and that he will also render the other eight idylls left into the beautiful language of Castile]

I fully agree with Vicente de Arana's claim, and I can only lament that he finally did not translate any other Idylls. But I would like to add something else. Lope Gisbert's high quality verse translation of a high quality and extremely sophisticated English verse, that typical of Tennyson's, proved that metrical translation of poetry, although difficult, is not impossible. That it must be rejected that the rendering of metrical verse into another language must necessarily be done in prose, as the aforementioned Vicente de Arana did when he translated The Idylls into Spanish.

Within the Spanish research literature devoted to this controversial issue, Esteban Torre (1994a) (1994b) stands out. He disagrees absolutely with the idea that there can be two different translation strategies or even norms to translate metrical poetry: prose and verse. Metrical poetry can only be translated into metrical poetry, no matter how difficult it is or seems to be. In poetry, linguistic form - syllable, rhyme, rhythm, alliteration, etc. - is an unavoidable part of the meaning, content or message. The problem is that the translator of poetry must be extremely competent in both the source language and target language metrics, and this is not easy at all.

Not easy, but not impossible, as the following enjoyable examples from Elena and Elaine by Lope Gisbert clearly show:

La hermosa Elena, Elena la adorable,

Elena la purísima azucena,

La Vírgen de Astolat, allá en su estancia

De la torre del Este, el noble escudo

De Lanzarote conservaba. Al pronto

Púsole en donde al despuntar le hiriera

El rayo de la aurora, y su reflejo

La despertara: más después, temiendo

Que la herrumbre ó el polvo le ofendiesen,

Una cubierta con sus propias manos

labró de rica seda; $y$ el ilustre

Blason bordó en su centro, $y$ caprichosa

Orla añadióle en torno de enlazadas

Hojas y flores, $y$ anidando en nidos

Pintados colorines.

(Gisbert: 3-4)

Elaine the fair, the lovable,

Elaine, the lily maid of Astolat,

High in her chamber up a tower to the east

Guarded the sacred shield of Lancelot; 
Which first she placed where morning's earliest ray

Might strike it, and awake her with the gleam;

Then fearing rust or soilure fashion'd for it

A case of silk, and braided thereupon

All the devices blazon'd on the shield

In their own tinct, and added, of her wit,

A border fantasy of branch and flower,

And yellow-throated nestling in the nest.

Nunca mujer alguna con un hombre

Fué más tierna y humilde. Le prestaba

Fuerzas su inmenso amor; hasta que un dia

El Ermitaño, práctico en la ciencia

De curar y del mundo, al ya salvado

Enfermo dijo, que á su dulce esmero

Debia la salud.

(Gisbert: 54)

And never woman yet, since man's first fall, Did kindlier unto man, but her deep love Upbore her; till the hermit, skill'd in all The simples and the science of that time, Told him that her fine care had saved his life.

Como inocente y sola

Avecilla en los bosques, que no sabe

Mas que una simple nota y la repite

Monótona, incesante una mañana

Entera de Setiembre, asi durante

Toda la noche la infeliz doncella

" iHe de morir!» se dice. A un lado y otro

Se vuelve y se revuelve, y no halla nunca

Sosiego, y sólo piensa: -«jÉl ó la muerte!»

«iLa muerte ó Él;!» y luego como un eco:

«iÉl ó la muerte!» lúgubre repite.

(Gisbert: 56)

Then as a little helpless innocent bird, That has but one plain passage of few notes, Will sing the simple passage o'er and o'er For all an April morning, till the ear Wearies to hear it, so the simple maid Went half the night repeating, 'Must I die?' And now to right she turn'd, and now to left, And found no ease in turning or in rest; And 'him or death' she mutter'd, 'death or him,' Again and like a burthen, 'him or death.'

«A vos, joh noble Lord, Sir Lanzarote! Yo, la azucena de Astolat llamada, Miéntras viví en el mundo, vengo á daros Mi postrimer adios, ya que sin darme Vos vuestro adios partisteis. Os he amado Sin ser de vos correspondida, y muero 
Por vuestro amor ... A nuestra Reina, á todas

Las nobles damas mi lamento envio.

Orad todas por mí; dad á mi cuerpo

Humilde sepultura ... Y tú que eres

Caballero sin par, joh Lanzarote!

¡Ora tambien por mí!»

(Gisbert: 78-80)

'More noble lord, Sir Lancelot of the Lake,

I, sometime call'd the maid of Astolat,

Come, for you left me taking no farewell,

Hither, to take my last farewell of you.

I loved you, and my love had no return,

And therefore my true love has been my death.

And therefore to our lady Guinevere,

And to all other ladies, I make moan.

Pray for my soul, and yield me burial.

Pray for my soul thou too, Sir Lancelot,

As thou art a knight peerless.'

Herido de cruel remordimiento

Así gemia Lanzarote. Nunca

Pudo ya ser feliz: pero fué al cabo

Bueno, y murió como los buenos mueren.

(Gisbert: 88)

So groan'd Sir Lancelot in remorseful pain,

Not knowing he should die a holy man

There is no doubt that Lope Gisbert is a very good translator. He faced a great challenge and rose to the occasion. He is faithful, but never literal or too literal. The examples presented here prove that he knows how to manage and take advantage of all the so-called "translation procedures": 'transposition,' 'modulation,' 'adaptation,' 'amplification,' 'concentration,' 'omission,' 'compensation,' etc. He seeks 'equivalence,' but not necessarily a 'word-for-word equivalence,' which is absolutely right, but rather an equivalence achieved through his phrases, sentences or paragraphs. He is also able the capture the original spirit, he sounds very Tennysonian. He understands the English poet's feelings, content, and intention. Gisbert also reproduces a beautiful language that seems appropriate.

The metrics constitute a different chapter in their own right. Lope Gisbert makes use of the closest Castilian verse form: the 'white hendecasyllabic verse,' to translate the original 'blank verse,' both unrhymed, as well as many internal rhymes, a consistent rhythm and, even, many examples of alliteration, a metrical phenomenon which is very popular in English, but much more unusual in Spanish: "And yellowthroated nestling in the nest / Hojas y flores y anidando en nidos."

In a few words, we have a poet translating another poet, and a high quality translation.

If we regard this translation case study from the point of view of Juliane House's translation model and translation quality assessment method, it can be claimed that this is a very good translation, and an almost perfect one, if perfection and translation can ever go together. Gisbert succeeded in rendering a sophisticated source text 
and, which can be regarded as very equivalent from their semantic, pragmatic and textual (metrical poetry into metrical poetry) meanings and forms. Their textual profiles and function are also "very" equivalent. We are very close to the ideal. Consequently, this is a good translation.

Is there anything in the model by Nord against regarding this translation as an excellent one? No, there is nothing at all.

\subsubsection{Ramón Sainero}

The purpose of this second translation of The Idylls by Tennyson is of a very different kind. Sainero did not publish, approximately a century later, a book about Tennyson only or a book aimed at translating Tennyson. His book, entitled Los grandes mitos celtas y su influencia en la literatura (1988), is a very ambitious monograph about Celtic culture and literature belonging to a whole series of books devoted to folktales, legends and myths. Tennyson is only one example among many: The Cuchulain, Ulster and Ossian Cycles; the Breton and Arthurian Cycles; the Irish Aimirgin, Ferguson or Yeats; the Scottish Macpherson or Walter Scott; the Welsh Taliesin, Dylan Thomas and R.S. Thomas; the English Layamon, Tennyson (Sainero 1988a: 232-217), Arnold or Williams; the French Chrétien de Troyes or Marie de France; and the Spanish García Gutiérrez, Espronceda or Pondal.

Besides, this is not the only book about this subject matter that Ramón Sainero, an authority on Celtic Studies, has published. The following titles can also be mentioned: La huella celta en España e Irlanda (1987), Leyendas celtas (1990), Sagas celtas primitivas (1993), or Lenguas y literaturas celtas: origen y evolución (1994).

Consequently, Los grandes mitos celtas y su influencia en la literature is many things at the same time: a history, a study and a multilingual anthology of texts with their corresponding translations into Spanish. A paramount comprehensive effort that focuses on old, medieval and modern writers; on Arthurian tales and nonArthurian ones; on all the so-called Celtic nations; on Celtic and non-Celtic languages: Middle English, Modern and Contemporary English, French, Medieval French, Galician, Spanish, different Celtic languages. And, as well as the translation of the original texts, the book is also well provided with general and specific introductions, notes, glossaries, etc., i.e., everything that can promote Celtic culture and literature among his Spanish readership. This is the writer's top aim, not the translations themselves.

Exactly, Tennyson and his Idylls are represented by two full compositions: the 518 lines of The Coming of Arthur and the 692 ones of Guinevere, and by 170 lines out of the 440 ones of The Passing of Arthur. In other words, the first, the last but one, and half the last of the definite version of idylls published only in 1889, when Tennyson finally finished his greatest work after a forty-year effort. Sainero could read this 1889 one when he translated in 1988, whereas this was impossible for Lope Gisbert when the translated his two idylls in 1875. Sainero also included the titles and ordering of all the idylls for his readers to know clearly what Tennyson did really write:

Dedication

The Coming of Arthur 


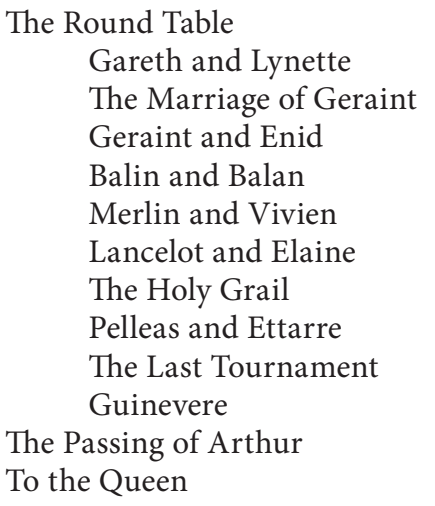

From this previous list of titles, it can be inferred that Sainero chooses the three idylls that include the names of Arthur and Guinevere, the leading Arthurian couple, as the most convenient examples of Tennyson for his comprehensive book. It is also very interesting to appreciate that he changes the order. He places the two idylls on Arthur first, and then the idyll on Guinevere follows the other two. He seems to struggle to devise a new logical order to his fragments, once the original one of twelve idylls is lost.

But the most interesting fact lies in the translation itself. The following examples of mine taken from the longer examples of his are very self-explanatory:

\section{La llegada de Arturo/The Coming of Arthur}

Leodogran, el rey de Cameliard,

Leodogran, the King of Cameliard,

tuvo una bella hija, y ningún hijo;

Had one fair daughter, and none other child;

y fue la más bella de todas las carnes de la tierra,

And she was fairest of all flesh on earth,

Ginebra, y fue ella su orgullo.

Guinevere, and in her his one delight.

Hubo muchos pequeños reyes antes que Arturo llegara,

For many a petty king ere Arthur came

gobernaron la isla, y siempre en guerra

Ruled in this isle, and ever waging war

unos contra otros, arruinaron la tierra:

Each upon other, wasted all the land;

y de vez en cuando la hueste pagana

And still from time to time the heathen host

en enjambres por el mar, llevaron lo que quedaba.

Swarm'd overseas, and carried what was left.

$\mathrm{Y}$ de esta manera crecieron grandes parajes yermos,

And so there grew great tracts of wilderness

donde la bestia cada vez más aumentó,

Wherein the beast was ever more and more,

y el hombre cada vez menos, hasta que Arturo llegó.

But man was less, till Arthur came.

Primero vivió Aurelio y luchó y murió,

For first Aurelius lived and fought and died 
y después de él el rey Uter luchó y murió, And after him King Uther fought and died, pero ambos fracasaron en formar un solo reino. But either fail'd to make the kingdom one. (Sainero 1988a: 234-235)

\section{La muerte de Arturo/The Passing of Arthur}

profundas praderas, alegres, bellas con campos frutales Deep-meadow'd happy, fair with orchard lawns $\mathrm{y}$ hogareñas hondanadas por el mar estival coronadas And bowery hollows crown'd with summer sea, donde curaré mi grave herida." Where I will heal me of my grievous wound.'

Diciendo esto, la barca con remos y vela So said he, and the barge with oar and sail se separó de la orilla, como un altivo cisne Moved from the brink, like some full-breasted swan que cantando un salvaje canto antes de su muerte That, fluting a will carol ere her death, escrespa su pura y fría pluma, entrando en la corriente Ruffles her pure cold plume, and takes the flood con oscuras telas. Mucho tiempo Sir Bedivere With swarthy webs. Long stood Sir Bedivere recordando hechos pasados estuvo, hasta que la barca Revolving many memories, till the hull pareció un punto negro en el vértice del alba, Look'd one black dot against the verge of dawn, y sobre el lago el gemido en la distancia fenece. And on the mere the wailing died away.

(Sainero 1988a: 278)

\section{Ginebra/Guinevere}

La reina Ginebra había abandonado la corte, y sentada Queen Guinevere had fled the court, and sat en la santa casa de Almesbury There in the holy house at Almesbury lloraba, nadie come ella excepto una pequeña doncella, Weeping, none with her save a little maid, una novicia, un pequeña luz entre ellas ardía A novice: one low light betwixt them burn'd empañecida por la reptante niebla, extensa fuera, Blurr'd by the creeping mist, for all abroad, bajo una luz cubierta pero llena, Beneath a moon unseen albeit at full, la blanca niebla, como un pañuelo en la cara, The white mist, like a face-cloth to the face, se agarraba a la muerta tierra, y la tierra estaba quieta. Clung to the dead earth, and the land was still.

Hasta aquí había huido, escapando For hither had she fled, her cause of flight de Sir Modred; quien como una astuta bestia 
Sir Modred; he that like a subtle beast permanecía agazapado con los ojos sobre el trono, Lay couchant with his eyes upon the throne, listo para saltar, esperando su oportunidad: por esto Ready to spring, waiting a chance: for this las populares alabanzas del rey

He chill'd the popular praises of the King con silenciosas sonrisas menospreciaba; With silent smiles of slow disparagement; y conspiraba con los señores del Caballo Blanco, And tamper'd with the Lords of the White Horse, paganos, la casta por Hengist dejaba, buscando Heathen, the brood by Hengist left; and sought dividir la mesa redonda de Arturo, To make disruption in the Table Round y desgajarla en pequeños feudos Of Arthur, and to splinter it into feuds que sirvieran sus traidores deseos; y todo su rencor Serving his traitorous end; and all his aims aumentado por su odio a Lancelot. Were sharpen'd by strong hate for Lancelot. (Sainero 1988a: 279-280)

Sainero's translation of The Idylls of the King is totally different from the one that Lope Gisbert did. Sainero is very literal and faithful to the content. He translates word-for-word. He does not make use of any 'translation procedure.' He does not care about reproducing any metrical means in the target language. His aim is not aesthetic or formal. His interest is only informative: to inform or spread the knowledge of the Celtic culture and literature in Spain. He does not have the interest, the time or the talent to translate faithfully the complex Tennysonian verse form, or just believes that it is an impossible or useless task.

But, is this a verse translation? Is this even a translation? Many will doubt it, if not clearly deny it is (word-for-word translation), Juliane House, for example. Finally, we can also wonder if this is a good translation. Absolutely not, from the principles of a source text-oriented model like House's one. There might be some semantic equivalence, but the pragmatic and textual ones are simply non-existing. The function and textual profiles are two very different things as well.

If we want to save this translation, this is the moment to ask for the help of Christiane Nord's model.

\section{The models and the critic}

The moment has also arrived to add some definite translation criticism about these two translations in accordance with the theoretical principles studied so far.

\subsection{Gisbert and House}

Lope Gisbert's translation seemed to be very equivalent and to adjust to what House regards as a covert translation - it looks like a second original - very well. But the closer you study the translated text the more you realize that it is not that evident. 
Gisbert's source text was the four-idyll version of The Idylls of the King published in 1859 , and that was re-published and made immortal in 1868 , illustrated by the French engraver Gustave Doré. This latter was the edition that Gisbert most probably made use of in 1875, which included four Idylls, all focusing on female characters: Elaine, Enid, Vivien and Guinevere.

The 1859-1868 work constituted a perfectly coherent unity that showed a marked contrast between the two false ladies: Vivien and Guinevere, and the two true ones: Enid and Elaine. Besides, we have another double contrast: a faithful wife, Enid, and an adulterous one, Guinevere; a full of love spiritual virgin, Elaine, and a full of hatred deceitful whore, Vivien. In other words, we have the well-known Victorian feminine stereotypes at work. Tennyson wanted it like this, and his contemporaries and readers understood the message very well, Lope Gisbert included.

But Gisbert only translated two of the stories: Elaine's and Enid's, i.e., only the true ones, not the evil ones. Why? I believe that this is not an innocent selection at all. That the translator knew what he was doing. His personality, ideology, moral principles, mentality and/or preferences are quite visible. He manipulated the source text. He censured Tennyson and only wanted to translate the good examples. Consequently, is there any semantic pragmatic and textual (the whole text taken into account) according to House left? Not much indeed. The function and the text profiles are quite different as well. Maybe it is not such a good translation after all, if House's model is to be strictly applied.

\subsection{Sainero and Nord}

What about Sainero's translations then? My help asking from Nord and her model has been answered. What is the function of the target text by Sainero? He wants to inform and to teach about Celtic language and literature by means of some translation samples taken from different writers, countries, periods and languages. This is what he needs and what he does. His translation is perfect from this point of view. The translation strategy chosen is also the right one. He rejects the original text appellative-aesthetic function and produces a new text provided with an overriding referential-informative (see illustrations). What was clearly wrong or bad, under the views of House, can now be regarded as a very talented, functional, brilliant translation. In other words, it is a translation that fulfils the intended objective very well. Consequently, congratulations to the scholar-translator.

\section{Conclusion}

\subsection{Two models and two translations compared}

Models can more or less be compared. They are the product of the development of time and the progress of knowledge. One model makes use of and then substitutes the previous one or ones. This is a life fact.

But translations are not like this. A new one is not necessarily better or worse than a previous one. There in not such time progress. Consequently, they are not easy to compare.

But if, for whatever reason, it must be done, it is important to do it from the viewpoints and assessment systems of as many translation models as possible. My 
opinion and perhaps my readers' opinion about Gisbert's and Sainero's translations of The Idylls of the King by Tennyson is that they have benefited greatly from both House's and Nord's theories. This is the best quality assessment method: a multifaceted one.

\subsection{The road}

My two-stop road from a text-oriented model to a functional one has been very rewarding not only to understand and learn some basic points about the evolution and theories available regarding translation, but also as a very practical tool for understanding and appreciating the achivements and shortcomings of two very different translations of Alfred Tennyson, the Difficult poet, Gisbert's and Sainero's. This has been my method as a critic, an "on-the-road" one.

\section{REFERENCES}

Anonymous (2001): “Where is the fire?," The Economist 360-8239, London, September 15th, pp. 77-78.

Arana, V. de (trans.) (1883): Poemas de Alfredo Tennyson. Enoch Arden. Gareth y Linette. Merlín y Bibiana. La Reina Ginebra. Dora. La Maya, ilustrados con dibujos originales de José Riudavets, D., Barcelona, C. Verdaquer.

Boughton, W. (1913): "Introduction," Alfred Tennyson: Idylls of the King (Selections), BostonNew York-Chicago-London, Ginn and Company, pp. i-xxv.

Bowden, M. (1930): Tennyson in France, Manchester, Manchester University Press.

Cervantes, M. de (1884): "Capítulo LXII. Que trata de la aventura de la cabeza encantada, con otras niñerías que no pueden dejar de contarse," El Ingenioso Hidalgo Don Quijote de la Mancha. Segunda Parte, Barcelona, Biblioteca Amena é Instructiva, pp. 337-346.

Cervantes, M. de (1993): "The Adventure of the Enchanted Head, with other impertinences not to be omitted," Don Quixote. Part Two, Ware (Hertfordshire, UK), Wordsworth Editions, pp. 722-730.

CoetzeE, J.M. (2001): Stranger Shores: Literary Essays 1986-1999, London, Viking.

Cuddon, J.A. (1992): Dictionary of Literary Terms and Literary History, London, Penguin Books.

Eliot, T.S. (1972): “In Memoriam,” Selected Essays, London, Faber and Faber.

Estébanez Calderón, D. (1999): Diccionario de términos literarios, Madrid, Alianza Editorial.

Gisbert, L. (trans.) (1875): Idilios de Tennyson puestos en verso castellano. Elena, Enid, Madrid, Medina y Navarro.

Новsваum, P. (1996): “Blank verse," Metre, Rhythm and Verse Forme, London, Routledge.

House, J. (1981): A Model for Translation Quality Assessment, Tübingen, Gunter Narr.

IRving, W. (1873): Tennyson, London, Maclachlan and Stewart.

Navarro Tomás, T. (1978): Métrica española. Reseña histórica y Descriptiva, Madrid-Barcelona, Ediciones Guadarrama-Labor.

Nord, C. (1991a): Text Analysis in Translation, Amsterdam/Atlanta, Rodopi.

Nord, C. (1991b): “Scopos, loyalty, and translational conventions," Target 3-1, pp. 91-109.

Nord, C. (1992): “Text Analysis in Translator Training," in Dollerup, C. and A. LoddegaArd, Teaching Translation and Interpreting: Training, Talent and Experience, Amsterdam and Philadelphia, John Benjamins, pp. 39-48.

Nord, C. (1997): Translating as a Purposeful Activity. Functionalist Approaches Explained, Manchester, St. Jerome.

Preminger, A. and T.V.F. Brogan (eds.) (1993): The New Princeton Encyclopedia of Poetry and Poetics, Princeton (NJ), Princeton University Press. 
Quilis, A. (1978): Métrica Española, Madrid, Ediciones Alcalá.

SAInero, R. (1987): La huella celta en España e Irlanda, Barcelona, Akal.

SAinero, R. (trans.) (1988a): "Alfred Tennyson," Los grandes mitos celtas y su influencia en la literatura, Barcelona, Edicomunicación, pp. 232-317.

SAINERo, R. (1988b): Los grandes mitos celtas y su influencia en la literatura, Barcelona, Edicomunicación.

SAinero, R. (1990): Leyendas celtas, Madrid, Akal.

SAInero, R. (1993): Sagas celtas primitivas, Madrid, Akal.

SAINero, R. (1994): Lenguas y literaturas celtas: origen y evolución, Madrid, Universidad Nacional de Educación a Distancia.

Shuttleworth, M. (1997): Dictionary of Translation Studies, Manchester, St. Jerome.

Tennyson, A. (1983): Idylls of the King, edited by Gray, J. M., Harmondsworth, Penguin.

Torre, E. (1994a): Teoría de la traducción literaria, Madrid, Síntesis.

Torre, E. (1994b): "Literatura y traducción," Reflexiones sobre la traducción, Cádiz, Servicio de Publicaciones de la Universidad de Cádiz, pp. 107-121. 